\title{
PROBLEMS OF IMPLEMENTATION OF THE EUROPEAN CHARTER FOR REGIONAL AND MINORITY LANGUAGES BY UKRAINE
}

\section{Tatiana Kovalova}

Law and European Integration Department, Kharkiv Regional Institute of Public Administration of the National Academy of Public Administration under the Office of the President of Ukraine, Moskovsky Prospect 75, 61001 Kharkiv, Ukraine,

e-mail: nojanojushka@gmail.com

\section{Citation}

Kovalova T., 2018, Problems of implementation of the European charter for regional and minority languages by Ukraine, Journal of Geography, Politics and Society, 8(3), 38-44.

\begin{abstract}
In the article the problems of implementation of the European Charter for Regional or Minority Languages are let on. In particular, it admits that during the years of its independence Ukraine didn't provide any system language policy and became a hostage of the signing of the Charter, as it undertook the responsibility to support and develop regional languages without any enactment of the law about the state language. As a result of political manipulations the provision of the functioning of Ukrainian language by the state was not made on a proper level. The latent language conflicts became a formal reason for the events in the Crimea and on the East of Ukraine and were used to invade the Ukrainian territories.
\end{abstract}

\section{Key words}

The European Charter for Regional or Minority Languages, language policy, status of languages, language relations, language situation, Ukraine.

\section{Introduction}

The language problem in Ukraine is still up-to-date, the argues according to the ways of solving the language issues continue during the whole period of the independence of the country swinging the society either to the side of the priority of Ukrainian language as the state one or to the side of the bilingualism codified by law. Unfortunately, the factors like the dalliance with different political actors, unconsequency in the implementation of the language policy, "pushing" the Law of Ukraine "About the fundamentals of the state language policy"
(Про засади..., 03.07.2012, № 5029-VI) in Verkhovna Rada played a dramatic part in the events of 2014 in Ukraine. It is understandable that it was not the language that became a reason for a military conflict, but the language was used as a tool of manipulations and the deconstruction of Ukrainian nation and Ukrainian state (Ковальова, 2010; Савойська, 2008; Сквірська, 2008).

As it is known, to see well you should not approach the subject but, vice versa, step aside. The background of the nearest past of the language policy of Ukraine answers a lot of questions of the present time. 
In September, 2000 the Program of the Integration of Ukraine to the European Union was approved by the Edict of the President of Ukraine, in particular, the Program admits the following: creating the conditions for Ukraine to get the membership in EU means, first of all, the necessity of conducting the corresponding reforms on the basis of execution of the Cooperation Agreement with the consequent reaching the fulfillment of Copenhagen criteria (Програма..., 2000; Copenhagen criteria..., 1993). In p. 2 chapter 1 of the Program one of the main directions of reaching the fulfillment of Copenhagen criteria is defined as "human rights and protection of the national minorities. First of all it includes the laws about citizenship, status of the state language and its teaching, migration policy and the corresponding institutions, the candidate country joining the fundamental international conventions in the defined area" (Програма..., 2000). In this way the Program confirms both the directions of the integration to the European legal and political space and the consequence of the steps in this directions.

But the analysis of the chronology of the establishing of the language legislation in Ukraine witness about the breach of the logic of the lawmaking. In 1999 Ukraine ratifies the European Charter for Regional and Minority Languages (hereinafter - Charter) (Європейська хартія..., 1992). Without making any lows of its own and without building the own model of the language regulation, Ukraine implements the European legislation aimed to protect regional and minority languages (in Ukrainian context they are the languages of the national minorities, as in this way the Charter was translated). Let us make a note that Ukraine and Armenia were the only postsoviet countries which signed the Charter.

In 2003 Ukraine ratifies the Charter for the second time (because of the violation of the procedures during the first ratifications) but none of the lawmakers remembers the responsibility to enact the law about the state language which was undertaken by Ukraine. So, as the researchers indicate fairly, the Charter signing was accompanied with political retarding, confrontation of the political wings, violation of the valid legislation, besides that the title of the Charter was translated incorrectly, so "this powerful international document made more harm to the language area in Ukraine then it made any good" (Кресіна, Явір, 2008, р. 190).

As it is indicated in the legal conclusion of the Ministry of Justice of Ukraine, the ratification of this Charter by Ukraine in a way it was done on the $15^{\text {th }}$ of May of 2003 has objectively caused appearing a range of pressing issues of legal, political and economic nature in Ukraine (Юридичний висновок...,
2006). The main reasons for this are both the incorrect official translation of the text of the document in Ukrainian, which was added to the Law about the ratification of the Charter, and the wrong understanding of the object and the purpose of the Charter.

The authentic texts of the Charter written in the official languages of the European Council appoint that this act of the international law tells not about "the regional languages or the languages of minorities" but about the single conceptual unit of "the regional and minority languages". And in paragraph 11 of the Explanatory Report to the Charter the following is indicated: "The purpose of the Charter is to protect and support the regional or minority languages, not the language minorities" (Європейська хартія..., 1992).

\section{Research discussions}

The European Charter for Regional and Minority Languages was approved by the European Council in 1992, when the language status as the state (official) languages was defined in many European countries long time ago, and for that moment the task for the European society was to maintain the right to use the regional and minority languages in private and public life considering the point that it was "an alienable right according to the principles declared in the International Pact of United Nations Organization about the civil and political rights and according to the spirit of the Convention of the European Council about the human rights and fundamental freedoms" (Європейська хартія..., 1992, р. 1).

To be fair we must indicate that not all of the European countries willingly recognized the language rights of their minorities because of fears of the threats to the state unity, for example, France, the United Kingdom, Greece, Turkey. "The fact that the Charter does not admire the countries-members of the European Council is obvious because of the fact it was ratified and valid in 24 countries of 47 only" (Бестерс-Дільгер, 2013, р. 13-14).

The language situation in Sweden, Norway, France, Germany, Ireland, Finland, Belgium and other countries show that the Charter is not a panacea in language relations regulation and, in particular, Y. Besters-Dilger (Бестерс-Дільгер, 2010), I. Bolman (Больман, 2007), Y. Shushliebina (Шушлєбіна, 2011) and others indicate.

In the Ukrainian language space when the Charter was approved the Russian language dominated, conditioned with the heritage of the Soviet past, the geographic close location of Russia and economic 
connections with it. Without creating the real conditions to confirm and protect Ukrainian language as the state one, Ukraine gives the legal support to 13 languages of the national minorities including Russian. And it happened, as Y. Besters_Dilger fairly indicates, because "Verkhovna Rada during the first and the second ratification was influenced by Russian and Russian-speaking deputies who aimed to compensate the failure of the attempt to implement Russian language as the second state language in the Constitution of 1996 via the acceptance of the Russian language to the Charter" (Бестерс-Дільгер, 2012, p. 13). So, "the Charter became the strongest political instrument to assist Russian language... The new de-Ukrainization is legitimized under the slogan of the said to be fulfillment of the European demands" (Бестерс-Дільгер, 2012, p. 14). It is clear that the European authors of the Charter did not take into their consideration the language situation in the post-soviet countries.

B. Bowring, who has been researching the language policy in Ukraine for more than 10 years, points to the special features of it. He indicates that "the language policy in Ukraine consisted of the exclusively complicated political and historical conditions, even comparing to the post-colonial problems of other countries, for example, Ireland, Spain or Turkey (Баурінг, 2008, p. 55).

The wide potential of the Charter had been started to use fully in Ukraine, especially by Russophones. During several months after its ratification the range of the regions of Ukraine declared that, on the basis of the Charter, they want to give a regional status to Russian language. One of the examples is Kharkiv region, where the population census of 2001 showed that $44,3 \%$ of the population of the region consider Russian language as the native one (Про кількість..., 2001). On the $6^{\text {th }}$ of March of 2006 Kharkiv city council was the first in Ukraine which approved the resolution about giving the status of the regional language to the Russian language in the city of Kharkiv (Про російську мову..., 2006). On the $3^{\text {rd }}$ of June of 2006 Kharkiv Regional Council approved the resolution to give the status of the regional language to Russian language in Kharkiv region, referring to the results of the Ukrainian population census of 2001, in accordance with which $83.1 \%$ of the inhabitants of Kharkiv region have fluent Russian (Про реалізацію..., 2006). The lead of Kharkiv was followed by Donetsk, Luhansk, Mykolayiv, Zaporizhzhia, Dnipropetrovsk, Kryvy Rih regions and thecity of Sevastopol.

Those resolutions were approved with the violation of the legislation of Ukraine, as neither the Constitution of Ukraine (Конституція..., 1996) nor the
Law of Ukraine "About Local Governing in Ukraine" (Про місцеве..., 1998), or other Ukrainian laws contain any provisions according to which solving the issues about the legal status of the languages which are in use in the work of the bodies of local authorities or within the territories of the corresponding territory communities do not belong to the incumbency of these bodies.

After enacting the Law of Ukraine "About the fundamentals of the state language policy" (Про засади..., 2012) of 2012 the situation with giving the status of the regional languages repeated. In the third periodical report of Ukraine about the execution of the European Charter for Regional and Minority Languages this situation was reflected (Third periodical..., 2016, p. 6). Russian language was recognized as the regional one in 9 regions of Ukraine: Donetsk, Zaporizhzhia, Luhansk, Mykolayiv, Odessa, Kharkiv, Kherson regions, the Autonomous Republic of Crimea and the city of Sevastopol. Hungarian language was recognized as the regional one in the cities of Chop and Berehiv and also in Uzhhorod, Vynohradiv and Berehiv districts of Zakarpattia region. Separate territories of Zakarpattia region recognized the Romanian language as the regional one (Tiachivsky district and 2 village councils of Rakhiv district). Also Romanian language was recognized as the regional one by the local councils in 4 districts of Chernivtsy region. Polish language was recognized as the regional one by just one village council of Storozhynetsky district of Chernivtsy region. Bulgarian language was recognized as the regional one in Kyrovohrad region by Znamianska village council and in Vilshansky district by 1 village council, and by Bolhrad district council of Odessa region, which also recognized Gagauz language as the regional one. Crimea Tatar language was recognized as the regional one in Novooleksiyivka settlement of Kherson region.

So, Ukraine unwillingly became a hostage of the Charter responsibilities undertaken by it which didn't meet the language and political situation of the post-soviet countries. Actually, after signing the Charter, Ukraine faced the problem of solving two mutually exclusive tasks: to consolidate Ukrainian nation around the state language and execute European liabilities according to the regional and minority languages.

Using the letter but not the intent of the Charter, the authors of the valid Law of Ukraine "Про засади державної мовної політики" (Про засади..., 2012), violating the balance of the languages protection, give a special status to the Russian language. It seems that if "the supremacy" of the language of one language minority over other languages. The 
European Commission for Democracy through Law (Venice Commission) in its conclusions about the project of the law "About the fundamentals of the state language policy" indicated this fact and noticed that besides the Article 10 of the Constitution of Ukraine separates the protection of the Russian language, the approach to the protection of this language must be implemented in the context of protection of other regional languages (Висновок..., 2011, art. 38). Considering the special features of Ukrainian language situation, the Commission stresses the additional guarantees to keep the state language as the instrument of the integration of the whole society (Висновок..., 2011, art. 41). But the Law was enacted without amending any considerable changes.

The irony of fate is in the fact that, though Russian language was given a wide protection and legal and actual priority above the languages of other minorities, it and the Russian-speaking citizens appeared to be unprotected facing the "Ukrainian nationalism". And, unfortunately, the language war turned to be a weaponed war: the slogan "protection of Russianspeaking population" was used by Russia to justify its actions on the East of Ukraine and the occupation of Crimea.

Though, while we were watching the East, the problems appeared in the West. On the $5^{\text {th }}$ of 2017 the deputies of Verkhovna Rada enacted the Law "Про освіту" which, in particular, confirms that education in all the Ukrainian schools (including those in places of the compact habitation of national minorities within bordering territories) must be provided in Ukrainian exclusively since the fifth grade (Про освіту, 2017, №3491-d, art. 7).

In short time after that the Ministers of External Affairs of Hungary, Bulgaria, Romania and Greece in their letter to their Ukrainian colleague Pavlo Klimkin declared their disturbance according to the new Ukrainian Law about education. Hungary asked the United Nations organization to investigate the law about education enacted by Ukraine with the following argumentation of this request; the law violates the right of the national minorities to use their language. After the law was signed by the President of Ukraine, the Hungarian side delivered the ultimatum to Ukraine that Hungary would not support any initiative of Ukraine in the international area until the language article of the Law "About Education" is canceled (Новий закон..., 2017)'.

\footnotetext{
1 According to the data of the Ministry of Education of Ukraine there are 71 Hungarian schools are working in Ukraine, where the teaching is made in Hungarian since the first till the eleventh form. The situation in Hungary is differ-
}

Now Hungary escalates the conflict with Ukraine via the law about education and is intended to block the Euro integrative initiatives of Ukraine and also the cooperation with NATO (Угорщина заблокувала..., 2017).

But Ukraine has own arguments according to the obligatory demand to obtain the education in the state language. The Ministry of Education of Ukraine L. Hrynevych stressed that now in Ukraine together with the stable tendency of increasing the number of pupils studying in the schools with the Ukrainian language of education, there is a threatening tendency - some schools with the education in the languages of the national minorities do not give the enough level of possessing the state language. "The situation of this kind means that the children after graduating the school do not have equal access to the higher education in Ukraine. According to the official statistics of the Ukrainian Center of the Education Quality Evaluation, in 2016 more than $36 \%$ of graduates of Zakarpattia passed the external independent testing on Ukrainian language with a result from 1 to 3 scores according to the 12 scores scale. These results mean that the third part of the graduates of Zakarpattia do not have any possibility to go to the higher educational institutions as the successful passing of EIT on Ukrainian is the obligatory demand when entering the higher educational institution", - Liliya Hrynevych admitted. The Minister added that children should leave schools being multilingual (Діти..., 2017).

Let us indicate that the main purpose to create the Charter was the aim to keep the language diversity of Europe, its destination is, first of all, to protect languages which have a small number of native speakers and which are threatened to vanish from the language map of the world. The main object of the support of the national states were, first of all, the state languages as the means of the national consolidation.

Considering the point that the language issue causes the lack of stability in the Ukrainian society, it is fit to consider the experience of European countries to use the Charter.

Let us observe the experience of France, Poland and Italy.

Choosing these countries for observation is conditioned with the different establishing of the status

ent. The Ukrainian diaspora is small when comparing it to the Hungarian minority in Ukraine - about 8 thousand people. Nevertheless, as Deutsche Welle writes referring to the data of the European Council, there are neither elementary nor secondary schools with the Ukrainian language of teaching in Hungary (Нуль..., 2017). 
of the languages of the title nation. In France there was a threat of displacement of French language by English. In the history of Poland there was a period (in the end of XVIII), when the Polish-Lithuanian Commonwealth stopped its existence as a state and its territory was divided between Austria, Prussia and Russia, which influenced the status and functioning of Polish language. The situation in these countries is similar to the situation in Ukraine: the long domination of the language of the non-title nation, displacement of the language of the title nation from the communication space, language bordering of the separate regions of the state and neighboring countries conditioned with its geographical position. So in all three countries there were periods when the languages of the title nations didn't have any proper development and the state support.

In Italy there was a different situation: Italian language was confirmed as the state one and today the support of the regional languages became actual.

The French Revolution started the beginning of the world national movement when the concept of the desirable identity of the state, nation and language developed (Бестерс-Дільгер, 2010). After the revolution French language was confirmed on the whole territory of the country. But after the Second World War English started to displace French from different areas, first of all from the science and economic activity, It was connected to the entrance to French economy of non-French transnational companies which used mainly English. Those circumstances conditioned French-English bilingualism in management, in the business, trade and advertisement area which caused increasing of the English language prestige.

In Article 2 of the valid Constitution of France the following is written the language of the Republic is French (La Constitution..., 1958). The Constitutional Council of France in spite of the fact that the profile Minister on the $7^{\text {th }}$ of May of 1999 signed the Charter on behalf of France prohibited to ratify it referring to the point that the Charter violates the principles of the Republic non-divisibility, equality before the law and unity of the French people and does not meet Article 2 of the Constitution.

Before accepting this change to the Constitution during the discussion it was said that it had to be aimed against English language exclusively and didn't have to interrupt the development of any regional languages (Agresti, 2008).

The Status of Polish language was defined in the Constitution of Poland of 1997. In Article 27 the following is indicated: the official language is Polish language and it doesn't violate the rights of the national minorities (Konstytucja..., 1997). Now the main legislation act regulating the functioning of Polish language is the law about Polish language from the $7^{\text {th }}$ of October of 1999. The preamble of the law underlines the meaning of Polish language for the national identity and culture: Polish language is the main element of the national self-identification and the richness of the national culture. The preamble also indicates that the law is enacted considering the historical experience "when the struggle of the enemies and occupants with the Polish language was the instrument of destroying of the national identity" and recognition of the necessity to protect the national uniqueness in a process of globalisation" (Ustawa..., 1999).

In Article 3 of this law it is said that protection of the Polish language is in the correct usage of Polish language and opposing to its vulgarization, spreading the knowledge of Polish language and respect to the dialects, spreading Polish language in the world and support studying Polish abroad.

In spite of 15 languages are recognized to be the languages of the national minorities in Poland, just one of them has the status of the regional one - the Cashubian (Reservations..., 2017). Together with this the language policy of Poland is aimed to make Polish language more popular not in the Republic of Poland only but in the countries of European Union too with the means of establishing the range of events, including studying of Polish language in the European countries where the Poles live (Pawłowski, 2006).

The analysis of the language situation in Italy shows that except the official standard (literature) Italian language which is used by a small part of native speakers and some mass media there are different forms of so called italiano regionale, the regional Italian language, a great number of dialects an a certain number of minority languages of other origin (Дель Гаудіо, 2014, р. 111). But Italy managed to consolidate the nation around the single "national" state. It happened, first of all, as a result of the following factors: (1) the above mentioned processes happened in time and in a corresponding historical context; (2) Italian literature language during its long history had an important cultural influence on the intellectual development not only the peninsula but the Europe in whole (Дель Гаудіо, 2014, p. 113). The important part was also played by the activity of Italian cultural and political activists which were oriented on a "sample" language of Dante, Petrarka and Boccaccio; (3) the knowledge of the national over regional literature language was one of the factors of the national unity. The ideal for the national patriots is "the language, common (Catholic) religion and the common Greek and Roman heritage" which, 
on its turn, served the aim of uniting the representatives of the intellectual elite of different Italian states of which the peninsula consisted before 1861 року (Дель Гаудио, 2014, р. 114).

But, representing the thought of a modern Italian, Del Gaudio fairly admits, that the axiom "one language - one nation" is not up to date any longer which is connected to the processes of globalisation which caused changes in the ideology and in attitude to the concept of "the national language". Today the contradictory ideological models are spreading aimed against the over domination of the national languages and on support of the languages of the national minorities.

\section{Conclusions}

As we can see, the experience of the language policy of the countries chosen for the research shows that the priority status in the model of language relations has the language of the title nation. And this situation is defining for most of European countries. In spite of ratification of the European Charter for Regional and Minority Languages by the countries the protection of the title language is an affair of the country itself and is beyond the area of responsibility of European institutions.

During 25 years Ukraine didn't manage to form a reasonable state language policy. The Law which became one of the instruments for manipulations with the consciousness of the Ukrainians and was used to justify the military conflict in Ukraine, remains the Achilles' heel of Ukrainian safety (Про засади..., 2012). Until the law about the state language is enacted and the measures to execute it are implemented, the language confrontation in Ukraine will exist.

The permanent refusals to solve the language question in Ukraine as they are not up to date demonstrated the lack of their basis: the reaction of people in social networks, the number of watching the videos on language problems on YouTube witness about the opposite. The Director of the Institute of Ukrainian language of the NAS of Ukraine P. Grytsenko fairly admits: "the confrontation about the language will remain until the role and place of each language in the life of our society - Ukrainian, Russian as the language of the national minority, other languages is clearly defined and underlined by the new law" (Глуховський, Груздєв, 2017).

So today the up to date issue for Ukraine is working out the project of the law about the state language and its enactment (Проект закону..., 2017). At the same time it is necessary to make amendments to the Law of Ukraine "About the ratification of the European Charter for Regional or Minority languages" (Про ратифікацію..., 2003), particularly to its part 2, in which, against the aims of the Charter, it is indicated that the Charter in Ukraine is applied not to the regional or minority languages but to the languages of the national minorities. The Law does not fix the languages on which the action of the Charter in Ukraine is spread, but just names the national minorities (not all of them) which live on the territory of Ukraine, and it cannot be executed in such an edition.

\section{References}

Agresti G., 2008, The European Charter for Regional or Minority Languages and France: stocktaking and prospects for a ratification in abeyance. Discourse analysis and the configuration of the, [in]: R. Dunbar, G. Parry (eds.), The European Charter for Regional or Minority Languages: Legal Challenges and Opportunities, Counsil of Europe, Strasbourg, 183-200.

Copenhagen criteria spelled out by the European Councils in Copenhagen 21-22 June 1993, 1993, European Commission, http://europa.eu/rapid/press-release_DOC-933_en.htm [30.11.2017].

Konstytucja Rzeczypospolitej Polskiej, 1997, http://www.wipo. int /wipolex/en/text.jsp?file_ [30.11.2017]

La Constitution du 4 octobre 1958, 1958, http://www.conseilconstitutionnel.fr/conseil-constitutionnel/francais/ la-constitution/la-constitution-du-4-octobre-1958/laconstitution-du-4-octobre-1958.5071.html [30.11.2017].

Pawłowski A., 2006, Problemy polskiej polityki językowej w Unii Europejskiej, Socjolingwistyka, 20, 7-17, http://docplayer.pl/5213163-Problemy-polskiej-polityki-jezykowe j-w-unii-europejskiej-1-adam-pawlowski-uniwersytet-wr oclawski.html [05.12.2017].

Reservations and Declarations for Treaty, 148 - European Charter for Regional or Minority Languages Declarations in force as of today Status as of 28/11/2017, 2017, https://www. coe.int/en/web/conventions/search-on-treaties/-/conventions/treaty/148/declarations [30.11.2017].

Third periodical report presented to the Secretary General of the Council of Europe in accordance with Article 15 of the Charter, Ukraine, 2016, Counsil of Europe, Strasbourg https:// rm.coe.int/16806f0f08 [30.11.2017].

Ustawa z dnia 7 października 1999 r. o języku polskim, 1999, Dz.U. 1999 nr 90 poz. 999, . http://prawo.sejm.gov.pl/isap. nsf/DocDetails.xsp?id=WDU19990900999 [30.11.2017].

Баурінг Б., 2008, Мовна політика в Україні. Міжнародні норми та зобов'язання і український закон та законодавство, [in:] Мовна політика та мовна ситуація в Україні. Аналіз і рекомендації, Видав. дім «Києво-Могилянська академія», Київ, 55-95.

Бестерс-Дільгер Ю., 2010, Сильні та слабкі сторони Європейської хартії регіональних або міноритарних мов: західноєвропейський досвід, Мовознавство, 1, 94-99. 
Бестерс-Дільгер Ю., 2012, Мовна політика України на тлі європейського та пострадянського досвіду, Наукові записки НаУКМА. Філологічні науки, 137, 12-16.

Бестерс-Дільгер Ю., 2013, Ефективність Європейської хартії регіональних або міноритарних мов як знаряддя захисту мовних прав у слов'янських країнах, Мовознавство, 5, 12-18.

Больман І., 2007, Мовні війни у Європі. Європейська хартія регіональних та меншинних мов, Видавництво «К.І.С.», Київ.

Висновок щодо проектузакону «Про засади державної мовної політики»: прийнятий Венечіанською комісією на 89Пленарномузасіданні 16-17 грудня 2011 року, Венеція, 2011, http://constituanta.blogspot.ru/2012/07/2011_11. html [30.11.2017].

Глуховський М., Груздєв С., 2017, Доктор філології Павло Гриценко:Мовні квоти - це ляпас усім українцям, http:// glavcom.ua/interviews/direktor-institutu-ukrajinskojimovi-pavlo-gricenko-movni-kvoti-ce-lyapas-usimukrajincyam-402601.html [10.03.2017].

Дель Гаудіо С., 2014, Міжмовні відношення та мовні права в Україні та Італії: порівняльний аналіз, [in:] Мовні права в сучасному світі, ПП Наумченко, Ужгород, 107-118.

Діти мають виходити зі школи багатомовними, - міністр, 2017 http://osvita.ua/school/55439/ [30.10. 2017].

Європейська хартія регіональних мов або мов меншин та пояснювальна доповідь, 1992, Секретаріат Європейської хартії регіональних мов або мов меншин, Страсбург https://rm.coe.int/belarus-brochure-uapdf/16807412ca [30.11.2017].

Ковальова Т., 2010, Мовні конфлікти як об'єкт державного регулювання, Теорія і практика державного управління, 1(28), http://www.kbuapa.kharkov.ua/e-book/ tpdu/2010-1/doc/3/15.pdf [30.11.2017].

Конституція України, 1996, Закон України № 254к/96-ВР, zakon.rada.gov.ua/go/254к/96-вр [30.11.2017].

Кресіна І., Явір В., 2008, Проблеми імплементації норм міжнародного права у національне законодавство про мови, [in:] Мовна ситуація в Україні: між конфліктом і консенсусом, ІПіЕНД імені І. Ф. Кураса НАН України, Київ, 190-204.

Новий закон про освіту: Угорщина уточнила свої вимоги до України, 2017 https://espreso.tv/news/2017/09/29/ novyy_zakon_pro_osvitu_ugorschyna_utochnyla_ svoyi_vymogy_do_ukrayiny [30.11.2017].

Нуль українських шкіл та жорстка мадяризація. Чи має право Угорщина погрожувати Україні?, 2017 https:// espreso.tv/article/2017/09/28/ugorschyna_ta_zakon_ pro_osvitu [30.11.2017].

Прозасади державної мовноїполітики, 2012, Закон України № 5029-Vl, zakon.rada.gov.ua/go/5029-17 [30.11.2017].

Про кількість та склад населення Харківської області за підсумками Всеукраїнського перепису населення 2001 року, 2001, http://2001.ukrcensus.gov.ua/results/ general/language/kharkiv/ [30.11.2017].

Про місцеве самоврядування, 1998, Закон України № 163-XIV, zakon.rada.gov.ua/go/280/97-вр [05.12.17]

Про освіту, 2017, Закон України №3491-d, http://zakon2. rada.gov.ua/laws/show/2145-19 [05.12.17].
Про ратифікацію Європейської хартії регіональних мов або мов меншин, 2003, Закон України № 802-IV, Відомості Верховної Ради України, 30, 259.

Про реалізацію конституційних гарантій на вільне використання російської мови в Харківській області та сприяння виконанню зобов'язань України щодо реалізації норм Європейської хартії регіональних мов або мов меншин, 2006, Рішення Харківської обласної ради № 10-V, http://www.ts.lica.com.ua/b_text. php?type=3\&id=781\&base $=77$ [30.11.2017].

Про російську мову в Харкові, 2006, Рішення Харківської міської ради № 43/06, http://kharkiv.rocks/reestr/356720 [30.11.17].

Програма інтеграції України до Європейського Союзу, схвалена Указом Президента, 2000, http://zakon3.rada.gov. ua/laws/show/n0001100-00/page [30.11.17].

Проект Закону про забезпечення функціонування української мови як державної, 2017, №5670-d http://w1.c1. rada.gov.ua/pls/zweb2/webproc4_1?pf3511=61994 [30.11.17].

Савойська С., 2008, Мовно-сепаратистські тенденції у політичному просторі України, Політичний менеджмент, 2, 76-88.

Сквірська В., 2008, “Мова - зброя політики”, або про мовні проблеми у пострадянській Одесі, [in:] Мовна політика та мовна ситуація в Україні, ВД “Києво-Могилянська академія", Київ, 167-195.

Угорщина заблокувала грудневе засідання комісії Україна-НАTO, 2017 http://www.eurointegration.com.ua/ news/2017/10/27/7072892/ [30.11.17].

Шушлєбіна Ю., 2011, Особливості мовної політики у країнах Європейського Союзу (на прикладі Ірландії та Фінляндії), Держава і право,з6. наук, праць, 54, 687-689.

Юридичний висновок Міністерства юстичії щодо рішень деяких органів місцевого самоврядування (Харківської міської ради, Севастопольської міської ради і Луганської обласної ради) стосовно статусу та порядку застосування російської мови в межах міста Харкова, міста Севастополя і Луганської області, 2006, https:// minjust.gov.ua/m/str_7477 [30.11.17]. 